\title{
Assessment of serum immunoglobulin and complement components level in patients with pulmonary tuberculosis
}

\author{
Imad A.J Thanoon*, Hani M. Salih**, Suhair M. Rashees*** \\ *Department of Pharmacology, **Department of Pharmacology.

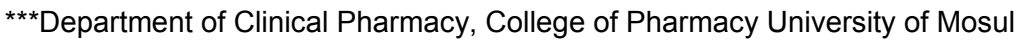

\section{ABSTRACT}

Objective: To assess, the serum levels of immunoglobulin $\operatorname{lgG}, \operatorname{lgM}, \lg A$ and, complement $\mathrm{Cr}$ and $C \leqslant$ in patients with pulmonary tuberculosis at diagnosis and $r$ months after therapy in comparison to age- matched healthy controls.

Methods: This case-control study was conducted at the Advisory Clinic for Chest and Respiratory Diseases at AL-Fasalaa in Mosul City and the Department of Pharmacology -College of Medicine University of Mosul during the period from December $r \ldots \vee$ to April $r \ldots \wedge$. Forty newly diagnosis patients with pulmonary tuberculosis were included in this study, with $\odot$. apparently healthy agematched subjects taken as a control. Initially from both the patients and the control group, blood sample were taken and assay of serum immunoglobulin levels $(\lg G, \lg \mathrm{M}, \lg \mathrm{A})$ and complements ( $\mathrm{Cr}, \mathrm{C} \varepsilon$ ) was done using single radial immunodiffusion method using commercial kits. After $r$ months of therapy another blood sample was taken from the patients group and assay of the same parameters was done.

Results :Initially, there was a highly significant increase in the serum levels of $\lg A, \lg M, \lg G$ and complement $\mathrm{Cr}$ in patients with active pulmonary tuberculoses with insignificant differences in the $C \leqslant$ levels in comparison to controls .

After $r$ months of therapy there was a significant reduction in the serum levels of $\operatorname{lgM}, \mathrm{Cr}$ with insignificant reduction in $\lg G, \lg A$ and $C \leqslant$ concentration in comparison to pre- therapy stage . In addition there was a significant differences in the serum levels of $\lg A, \lg G, C^{r}$ in comparison to controls .

In conclusion Tuberculosis as a disease and anti- tuberculous therapy do affect the immune system as reflected by the serum immunoglobulin $\lg A, \lg M, \lg G$ and complements $(C r, C \varepsilon)$ levels.

:Keywords: pulmonary T B, immunoglobulin IGG, IGA, IGM, complements (C',Cr)

تحديد المستوى المصلي للكلوبيولينات المناعية والمتممات في مرضى التدرن الرئوي

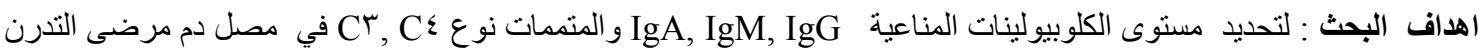

الرئوي عند التشخيص وبعد ثلاثة اشهر من تلقي العلاج بالمقارنة مع مجموعة الضبط من اشخاص اصنية الشحاء من اعمار مقاربة لاعمار

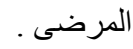

التصميم : دراسة عينية مقارنة 


$$
\begin{aligned}
& \text { مكان اجر اء البحث و الاطار الزمني : } \\
& \text { تم اجر اء البحث في عيادة الامر اض الإن الصدرية في منطقة الفيصلية في الموصل وفي فرع الادوية كلية الطب - جامعة الموصل للفترة }
\end{aligned}
$$

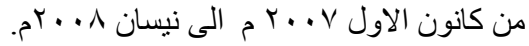

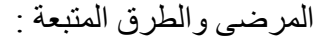

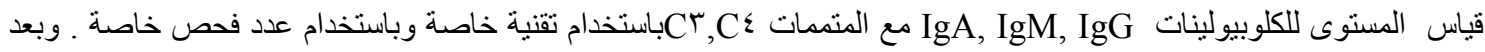

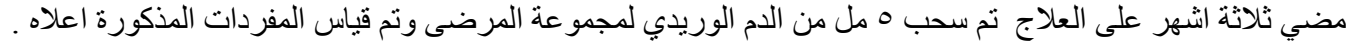

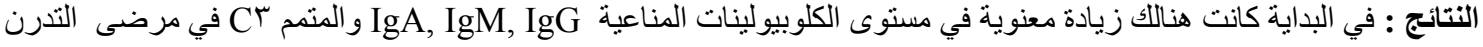

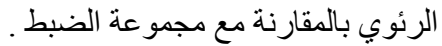

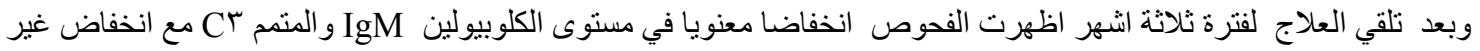

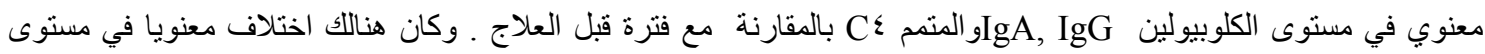

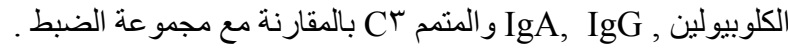

$$
\begin{aligned}
& \text { الاستنتاج : التندرن الرئوي كمرض و العلاج المضاد للنترن يؤثر فعليا على جهاز المناعة ممثلا بالتاثير على مستوى الكلوبيولينات }
\end{aligned}
$$

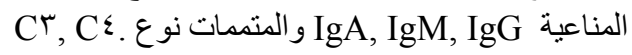

$\mathrm{T}$ uberculosis (TB) is still a major health problem in most developing countries and its incidence is rising in many developed countries.' Humoral immunity has a role to play in host defense against infection, particularly of bacterial origin. The role of humoral response in immunity to tuberculosis is unclear and clinical studies have yielded inconsistent conclusions, ${ }^{r, r}$ but recently it has been widely recognized and utilized in serologic diagnostic procedures. .Information's regarding immunoglobulin levels in patients with TB is surprinsingly scant, ${ }^{\circ}$, and there are only a few reports about the complement components and their important role in the development of immunlogically mediated inflammatory reactions. ", The aim of this study is to evaluate the serum levels of immunoglobulin $\lg G$, $\lg A$ and $\lg M$, and complements $\mathrm{Cr}$ and $\mathrm{C} \varepsilon$ in newly diagnosed cases with pulmonary TB, initially and after $r$ months of standard first line therapy in comparison to healthy controls.

\section{Patients and Methods}

The study was conducted in the Department of Pharmacology College of Medicine and the Advisory Clinic for Chest and Respiratory Diseases at Al-Fasalaa in Mosul city from December $r \ldots \vee$ to April $r \ldots \wedge$. Patients were selected according to certain criteria, which included newly diagnosed patients with pulmonary TB (proved by sputum smear examination and chest x-ray), cooperative and compliant, accepting the follow up period, with no other diseases as hypertension, renal disease, liver disease or diabetes mellitus, and all planned for the same first line antituberculosis therapy.

Out of $\leqslant r$ patients interviewed and examined only $\leqslant r$ included in the study of whom only $\varepsilon$. completed the study. Also, included 0 . apparently healthy subjects taken as a control group. Initially from both groups (patients and control), $\circ \mathrm{ml}$ of venous blood samples were taken at $1 \cdot A M$ and assay of serum immunoglobulin (IgG, IgA, IgM ), and complements $\left(\mathrm{Cr}^{r}, \mathrm{C} \varepsilon\right)$ was done by single radial immunodiffusion method, ${ }^{\wedge}$ using commercial kits . For the patient's group, after $r$ months of therapy, another blood sample was taken and assay for the same parameters was done.

Each patient under study was given \& coated tablets (from Svizera labs, India) in the morning for the initial $r$ months of therapy, and each tablet contained isoniazid (INH) vo $\mathrm{mg}$, rifampicine $10 . \mathrm{mg}$, pyrazinamide $\leqslant \cdots m g$ and ethambutol rvomg with vitamin $\mathrm{Br}^{\mathrm{l}}$. $\mathrm{mg}$ daily. In the subsequent phase of therapy each patient was given $\mathrm{INH} r \cdots \mathrm{mg}$ and rifampicine $r \cdots \mathrm{mg}$ with vitamin $\mathrm{Br}^{\mathrm{r}} \mathrm{l} \cdot \mathrm{mg}$. 
All values were quoted as mean $\pm S D$ and a $p$ - value <... 0 was considered to be statistically significant. Unpaired t-test was used to compare results of patients initially and after $r$ months of therapy with that of the controls. Paired t-test was used to compare results of patients in the pre and post therapy stages.

\section{Results \\ control group}

Fifty-apparently healthy volunteers, were taken as a control group. They were $r$ males and I $\leqslant$ females, and their ages varied between $r$. to $v$. years with mean \pm SD of $\leqslant 1 . \wedge+1 \leqslant . r$ years.

\section{Patient group}

Forty newly diagnosed patients with pulmonary tuberculosis were included in this study. They were $r 9$ males and 11 females, and their ages varied between $r \cdot$ to $\uparrow$ years with mean $\pm S D$ of $r q .9 \pm 1 r$. $\{$ years.

\section{Pre therapy stage}

There was a highly significant increasein the serum levels of $\lg G, \lg A, \lg M$ and $\mathrm{Cr}$ in patients with pulmonary tuberculosis $(p<\cdot, \cdot)$ in comparison to controls, while complements $\mathrm{C} \leqslant$ levels showed insignificant difference ( Table 1).

\section{Post therapy stage}

By comparing values of parameters under study before therapy and $r$ months after therapy there was a significant reduction in the serum levels of $\operatorname{lgM}$ and complement $\mathrm{Cr}$, with insignificant reduction in the serum levels of $\lg G, \lg A$ and complement $C \leqslant$ (Table r).

By comparing values of parameters under study in post therapy stage with that of the control there was a significant differences in the levels of $\lg G, \lg A$ and complement $C^{r}$ with insignificant difference in the levels of $\operatorname{lgM}$ and complement $\mathrm{C} \leq$ (Table ${ }^{\mathrm{T}}$ ).

Table !: comparison of the measured parameters between control and patient with tuberculosis before therapy.

\begin{tabular}{|c|c|c|c|}
\hline \multirow{2}{*}{$\begin{array}{c}\text { Parameters } \\
\text { mg/dl)( }\end{array}$} & \multicolumn{2}{|c|}{ Mean \pm SD } & \multirow[b]{2}{*}{ p-value } \\
\hline & Control $(n=\bullet \cdot)$ & Pre- therapy Patients $(n=\varepsilon \cdot)$ & \\
\hline IgG & $1 . \leqslant 0 \pm 1 \cdot 1.74$ & Iro. $\underline{\text { Irr.VE }}$ & $<\because \cdots 1$ \\
\hline $\operatorname{IgA}$ & 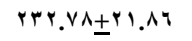 & $r v \checkmark . T V_{ \pm} r 0.01$ & $<\bullet, \cdot 1$ \\
\hline IgM & $109 . v r_{ \pm} r^{0.91}$ & $110.71 \pm 18.7 \mathrm{~V}$ & $<\cdot \cdots+1$ \\
\hline $\mathrm{Cr}^{\mathrm{r}}$ & $191 . \cdot 7 \pm 10 . r V$ & $r .9 .9 \pm+11.9$ & $<\cdot . \cdot 1$ \\
\hline$C^{\varepsilon}$ & $r ५ . Y 0_{ \pm} \leqslant . \wedge v$ & $r v . T v_{ \pm} 0 . T \varepsilon$ & $\cdot \operatorname{rrv}(\mathrm{NS})$ \\
\hline
\end{tabular}


Irq J Pharm Vol. $\vee \& \wedge$, No. ', r..^

Table r.: comparison of the measured parameters between patients with tuberculosis before and after therapy

\begin{tabular}{|c|c|c|c|}
\hline \multirow{2}{*}{$\begin{array}{l}\text { Parameters } \\
\text { (mg/dl) }\end{array}$} & \multicolumn{2}{|c|}{ Mean \pm SD } & \multirow[b]{2}{*}{$p$-value } \\
\hline & pre- therapy Patients & post- therapy Patients & \\
\hline $\lg G$ & KO. ITr.VE & $1 r \cdot 9.9 \pm \pm 1.9 .7 V$ &. $.109(N S)$ \\
\hline $\lg \mathrm{A}$ & rVI.TVE $+Y 0.01$ & $r \pi v_{.}\left(q_{ \pm}+1 \leq .0 r\right.$ & $\because \wedge l(N S)$ \\
\hline $\lg M$ & $110.71 \pm 17.7 \mathrm{~V}$ & $107 . \cdot 7 \pm r \leqslant . V \varepsilon$ & $<\cdot \ldots 1$ \\
\hline Cr & $r \cdot 9.9 \pm 11.7$. & $177 . r 7 \pm 10.01$ & $<\cdot \ldots 1$ \\
\hline$C \varepsilon$ & $T V . T V \pm 0.7 \leq$ & $r 0.9 v \pm \varepsilon . \cdot 1$ & $.10 \leqslant(N S)$ \\
\hline
\end{tabular}

Table ( $r$ : comparison of the measured parameters between controls and patients with tuberculosis after therapy

\begin{tabular}{|c|c|c|c|}
\hline \multirow{2}{*}{$\begin{array}{l}\text { Parameters } \\
\text { mg/dl)( }\end{array}$} & \multicolumn{2}{|c|}{ Mean \pm SD } & \multirow[b]{2}{*}{ p-value } \\
\hline & Control $(n=0 \cdot)$ & Post-therapy Patients $(n=\varepsilon \cdot)$ & \\
\hline $\lg G$ & $1 \cdot \leqslant 0 \pm 1 \cdot 1.74$ & $1 r \cdot 9.9 \pm+1 \cdot 9.7 v$ & $<\cdot, \cdot 1$ \\
\hline $\lg \mathrm{A}$ & $Y r Y . V A \pm Y l \cdot \wedge T$ & $r 41 . \vee 9 \pm 1 \leqslant .0 r$ & $<\cdot \ldots 1$ \\
\hline $\lg M$ & $109 . V Y \pm Y 0.91$ & $107 . \cdot 7 \pm r \leqslant . V \varepsilon$ &. .001 (NS) \\
\hline Cr & $191 . \cdot 7 \pm 10 . r V$ & $177 . r 7 \pm 10.01$ & $<\cdot, \cdot 1$ \\
\hline$C \leqslant$ & $r T . Y O \pm \sum . A Y$ & $r 0.9 v \pm \varepsilon .11$ & $\because \vee \vee \vee(N S)$ \\
\hline
\end{tabular}




\section{Discussion}

Our data showed a significant increase in the serum levels of $\lg G, \lg A, \lg M$ and complement $\mathrm{Cr}^{\mathrm{r}}$ in patients with active pulmonary TB before therapy in comparison to controls, and a significant reduction in the serum levels of IgM and complement $\mathrm{Cr}^{r}$ after $r$ months of anti TB therapy in comparison to pre- therapy stage.

Diagnosis of pulmonary TB is mainly based upon the clinical, radiological and bacteriological evidence, however, a serologic diagnostic test, would have considerable and obvious advantages? Information with regard the effects of tuberculosis and antituberculosis therapy on immunoglobulins and complements level were scanty,old and with somewhat conflicting data. The first study about the subject came in $19 \times 1$ by Alakcon- Sefovia and Fishbein, and there findings indicated a significant raise in all $r$ types of immunoglobulin (IgA, IgG, IgM )in comparison to healthy controls ${ }^{\varepsilon}$. Wong and Saha (199.) , reported a significant increase in the serum levels of $\lg G$ and $\lg M$, with no change in the $\operatorname{lgA}$ and complement Cr levels in newly diagnosed cases with pulmonary TB '.

Sharma and Coworkers, in a research concerning cases with miliany TB, reported a significant raise in the levels of $\lg G, \lg A$ and IgM in the serum and broncho-alveolar lavage fluid (BALF) in those patients, moreover the serum complement $\mathrm{Cr}$ levels and raised levels of $\lg G, \lg A$ in the serum and BALF persisted by the end of the 9 months anti TB therapy.".

In keeping with our findings, Suzuki and Colleages, in a study about the sequential changes of serum acute phase receding in response to anti- tuberculosis reported a significant reduction in the serum immunoglobulin levels after receiving therapy, so as C- reactive protein and erythrocyte sedimentation rate $(E S R)^{1 r}$.

The complement levels and in agreements with our results, Sai Baba et al, reported a significant Increase in the serum levels of complement $\mathrm{Cr}$ in untreated patients with pulmonary $\mathrm{TB}$ in comparison to treated groups of patients and healthy controls't. Furthermore, Dubaniewcz and Sztaba Kanin, reported a significant elevations in complements $\mathrm{Cr}$ levels in active cases of pulmonary TB in comparison to inactive cases and healthy controls and a tendency towards significant reduction in its level after $r$ months of therapy ${ }^{\prime \text {. }}$.

Yildirim and Colleages, assessed the complement and immunoglobulin levels in the serum and ascetic fluid in patients with TB ascites in comparison to bacterial peritonitis and malignant ascites. They reported an increase in the serum IgM, complement $\mathrm{Cr}^{r}$ and $C \leqslant$ with an increase in the $\lg M, \lg A, \lg G$ in the ascitis fluid of patients with TB ascites ${ }^{\vee}$. The elevated in the serum and ascetic fluid of complements $\mathrm{Cr}^{r}$ could be attributed to several mechanisms, such as inhibition of serum and ascetic fluid complement -factor consumption and/or improved hepatic complement synthesis. ${ }^{10,14}$

A recent study by Dubaniewcz and Coworkers in $r \cdots \varepsilon$, about immunoglobulin parameters in pulmonary TB, reported a significant increase in the serum levels of $\lg \mathrm{G}, \lg \mathrm{A}$ and complements $\mathrm{Cr}, \mathrm{C} \leqslant$ their patients in comparison to healthy controls ${ }^{r}$. In $r . . \circ$ a study conducted by Gupta and Colleages, studied the serum level of IgG subclasses in patients with active pulmonary TB. They reported a significant elevation in $\lg G), \lg G r$ with moderate raise in $\lg G r{ }^{.}{ }^{\text {V }}$

The elevation in the immunoglobulin levels in patients with pulmonary tuberculosis, reported in the present work may be interpreted as a humoral response to mycobacterial antigens. ${ }^{\wedge}$

In conclusion tuberculosis as a disease and anti-TB therapy do affect the immune system as reflected by the levels of immunoglobulin $(\lg G, \lg A, \lg M)$ and complements $(C r, C \varepsilon)$ in comparison to healthy controls.

\section{References}

1. Bhatia AS, Kumar S , Harinath BC. Immunodiagnosis of tuberculosis : An update . Indian J Clin Biochem $r \ldots r, I \wedge(r)$ :1-0. 
r. Giasuddin ASM, Gad MA, Ziu MM. Humoral immune response in Libyan patients with chronic and acute bacterial infections. J Islamic Acad Sci $199, r(r)$ : Irq-1 $\leqslant$ r.

£. Alarcon -Segovia D, Fishbein E. Serum immunoglobulins in pulmonary tuberculosis. Chest 19V1; $7 \cdot: 1 r T-1$ T

- Buckly CE, Dorseg MA, A comparison of serum immunoglobulin concentrations in sarcoidosis and tuberculosis. Ann Intern Med $19 Y \cdot ; V Y: Y Y$.

7. Jose $P$ Complement -derived peptide mediators of inflammation. $\mathrm{Br}$ Med Bull 19人v; \&r: rrч

v. Yildirim B, Sari R, Sezgin N, Sevinc A, Hilmioglu F. Complements and immunoglobulin levels in serum and ascetic fluid of patients with spontaneous bacterial peritonitis ,malignant ascites and tuberclous peritonitis. South Med J r...r; $90(1 \cdot): 1101-117 \%$.

^. Mancini G, Carbonara AO, Heremans JF . Immunochemical quantitation of antigens by single radial immunodiffusion. Immunochemist 1970;r:rro-ros.

9. Jain VK, Bishnoi HS, Beniwal OP, Misra $\mathrm{SN}$. Immunoglobulin profile in pulmonary tuberculosis. JPGM $19 \wedge \varepsilon ; r \cdot(r): \wedge \cdot-\wedge \varepsilon$.

$1 \cdot$.Wong CT, Saha N. Changes in serum proteins (albumin, immunoglobulin and acute phase proteins) in pulmonary tuberculosis during therapy. Tlubecle $199 \cdot ; 1(r): 19 \%-19 \%$.

11.Sharma SK, Pande JN, Singh YN, Verma K, Kathait SS, Khara SD , etal. Pulmonary function and immunoglobulin abnormalities in miliary tuberculosis . Am Rev Respir Dis 1994;। $\left\{0(0): 117 V_{-} 11 \mathrm{~V}\right.$. r. Dubaniewicz A, Sztaba -Kania M, Hoppe A. Analysis of some immunoglobulin parameters in pulmonary tuberculosis. Pol Merkuriusz Lek r. $\varepsilon \varepsilon ; 1\}$ (qr) : Irr-Irr.

1r. Suzuki K, Takashima Y, Yamada T, Akiyama J Yagi K, Kawashima M,etal. The sequential changes of serum acute phase reactants in response to anti tuberculosis chemotherapy . Kekkaku 199r; $\urcorner \vee(\xi): r \cdot r-$ ril.

1r.Sai Baba KS, Moudgil KD, Jain RC, Srivastava LM. Complement activation in pulmonary tuberculosis . Tubercle 199.; r)(r): $1 \cdot r-1 \cdot r$.

I \&.Dubaniewicz A, Sztaba -Kania M. Circulating immune complex and complement $\mathrm{Cr}$ in a course of pulmonary tubecolusis . Pol Merkuriusz Lek $r \ldots r ;$; $(V Y): \leqslant 91-\leqslant 90$.

10. Fromkes JJ, Thomas FB, Mekhjian HS, Evans M. Antimicrobial activity of human ascetic fluid. Gastroenterol $19 \vee v ; V r: T r \Lambda$ TVY.

17. Colter HR, Alper CA, Rosen FS . Current concepts in immunology, genetics and biosynthesis of complement proteins . $\mathrm{N}$ Eng J Med 1911;r. . : 70r-707.

IV. Gupta S, Shhende N, Bhatia AS, Kumar S, Harinath BC. IgG subclass antibody response to mycobacterial serine proteins at different stages of pulmonary tuberculosis. Med Sci Monit r...0;1)(Ir): 0N0.01N.

i ...Skvor J, Trkna E, Kugukova Z. Immunoprofile studies in patients with pulmonary tuberculosis. Correlation of levels of different classes of immunoglobulin and specific antibodies with the extent of tuberculosis. Scand J Dis $19 \vee 9 ; 7 \cdot: 17 \Lambda-1 V 1$. 